\title{
Rice husk ash and its utilization in soil improvement: An overview
}

\author{
Duong Thanh Nguyen *, Nu Thi Nguyen, Ha Ngoc Thi Pham, Hai Huu Phung, Hung \\ Van Nguyen
}

Faculty of Geosciences and Geoengineering, Hanoi University of Mining and Geology, Vietnam

\begin{abstract}
ARTICLE INFO
ABSTRACT

Article history:

Received 21stFeb. 2020

Revised 23rd May 2020

Accepted $30^{\text {th }}$ June 2020

Keywords:

Agricultural by-product,

Burning time,

Chemical binders,

Rice husk ash (RHA),

Soil improvement,

Temperature.

The utilization of waste materials in soil improvement is the potential for the reduction of the negative effect on the environment and the construction cost as well. One of the waste materials is rice husk ash (RHA), which is an agricultural-by product and can be utilized for soil improvement. This paper aims to present a comprehensive review of the numerous investigations on rice husk ash and its utilization in soil improvement. Based on the literature review, there are some findings as follows: (i) burning rice husk ash in incinerator under a controlled temperature of $500 \div 800^{\circ} \mathrm{C}$ and time of $1 \div 4$ hours will produce $R H A$ with high pozzolanic activity; (ii) the RHA can be considered as a stabilizer for different types of soil, and it can be used in combination with different chemical binders and waste materials for soil improvement; (iii) from the view of engineering purposes, the RHA from about 3 to $20 \%$, the lime from 2 to $9 \%$, the cement from 2 to $15 \%$ were mostly suggested to improve the soil for pavement, road (base and sub-base layers), and building houses in rural areas. However, the research on the utilization of RHA in soft ground improvement by deep mixing method using lime and cement is still limited, and it is therefore recommended for further research. In addition, the experimental field research on the utilization of RHA for soil improvement in engineering practice needs to be conducted.
\end{abstract}

Copyright (C) 2020 Hanoi University of Mining and Geology. All rights reserved.

\section{Introduction}

Soil improvement for engineering practice has been introduced for many years. The main

${ }^{*}$ Corresponding author E-mail: nguyenthanhduong@humg.edu.vn DOI: $10.46326 / J M E S .2020 .61(3) .01$ purpose is to help the soil meet the requirement of the specific engineering projects. Soil can be improved by mixing with chemical binders (cement, lime) and/or with waste materials (fly ash, bottom ash, rice husk ash, steel slag,etc.). Traditionally, chemical binders such as cement, lime are often used for soil improvement. However, the production of cement and lime requires enormous heating and can release a huge 
amount of carbon emission. Hence, the use of these common binders for soil improvement can make negative effects not only on the environment but also on the construction cost (Liu et al., 2019b). In addition, the waste materials as mentioned above often cause a serious problem for the environment. Therefore, the use of these waste materials for soil improvement or partial replacement of cement, lime in soil improvement will help to reduce the negative effects on the environment and the construction cost as well (Nguyen Thi Nu et al., 2020).

Among waste materials, as mentioned above, rice husk ash (RHA) is abundant in many countries, especially in developing countries such as Vietnam, China, Indonesia, and India, etc. RHA is an agricultural by-product material that is resulting from burning rice husk. As estimated, the annual rice production is about 500 million tonnes in the world. As a result, about 100 million tonnes of rice husks are produced annually. Rice husk is often disposed of or can be burned in open heaps or used as fuel for fruit drying and power generation, as it is very abrasive and not suitable for animal feed. If rice husk is burned, about 20\% of the mass remains as rice husk ash (RHA). It means that a huge amount of about 20 million tonnes of RHA can be produced every year in the world (Jongpradist et al., 2018). However, a large amount of RHA is often disposed to the environment. Since RHA is porous and very light, it can be carried easily by the wind, thus polluting the air and water. Therefore, an increase in the utilization of RHA will have great potential for waste management. RHA is high in silica with content above 70\% (Fapohunda et al., 2017). Silica in RHA possesses little cementing properties, but it can react with calcium hydroxide such as lime to form cementitious compounds (pozzolanic reaction), which can bind the soil particles and enhance the soil strength (Behak, 2017). In fact, chemical binders such as cement and lime are often used to enhance the soil strength. Nevertheless, the lime and cement are much more expensive than RHA. In addition, the production of lime and cement consumes a lot of heating energy and releases a huge amount of carbon dioxide. Therefore, the utilization of RHA for soil improvement will reduce the negative effect on the environment and the construction cost as well. The main purpose of this review is to update and to gather all research works relating to RHA and its utilization in soil improvement. The review results of this research will provide useful information and direction for further investigations. The present research includes three main parts: production and physical properties of RHA; chemical compositions of RHA; and utilization of RHA in soil improvement.

\section{Production and physical properties of RHA}

\subsection{Production of RHA}

RHA can be produced by burning rice husks in open heaps, bio-mass power plants without controlling temperature or in incineration furnace under controlled temperature conditions. The quality of RHA significantly depends on the combustion condition (temperature, burning duration, cooling time, and burning type) and will affect the effectiveness of RHA in soil improvement (Basha et al., 2005). Houston (1972) classified RHA into three types: highcarbon char (black), low-carbon ash (grey), and carbon-free ash (pink or white). The changes of color are associated with the completeness of the burning process (temperature and burning duration) and the transformation of the silica in the ash. The light color will result in the lower carbon content and the higher silica content in the ash. The amorphous silica is suitable for a pozzolanic reaction rather than crystallized silica. Behak (2017) found that the RHA from burning rice husk in a controlled temperature of $6500 \mathrm{C}$ $8000 \mathrm{C}$ (in incinerator) was more reactive than the one that from burning in uncontrolled temperature (in conventional ovens). Cordeiro et al. (2009) revealed that RHA obtained from uncontrolled burning conditions often contained high carbon content with low pozzolanic activity. Nguyen et al. (2011) also stated that the RHA with high reactive silica content cannot be obtained from open burning of rice husk and burning rice husk below the temperature of $500^{\circ} \mathrm{C}$. Under uncontrolled conditions, the RHA from bio-mass power plants and open burning were not fully burned and contained a high carbon content and high loss of ignition (LOI) (Karatai et al., 2016; Liu et al., 2019a, b). 
Table 1. Summary of controlled conditions for the production of RHA with high pozzolanic activity

\begin{tabular}{|l|l|}
\hline \multicolumn{1}{|c|}{ Temperature and burning time for the production of RHA } & \multicolumn{1}{c|}{ References } \\
\hline Up to $900^{\circ} \mathrm{C}$ with burning time of less than 1 hour & Yeoh et al., 1979 \\
\hline From $500 \div 600^{\circ} \mathrm{C}$ & Hamad and Khattab, 1981 \\
\hline From $550 \div 700^{\circ} \mathrm{C}$ & Boateng and Skeete, 1990 \\
\hline From $650^{\circ} \mathrm{C}$ and burning time of 1 hour & Asavapisit and Ruegrit, 2005 \\
\hline From $500 \div 600^{\circ} \mathrm{C}$ or at $350^{\circ} \mathrm{C}$ if the combustion time is 15 hours & Bui et al., 2005 \\
\hline From $500^{\circ} \mathrm{C}$ and burning time of about 2 hours & Al-Khalaf and Yousif, 1984 \\
\hline From $500 \div 700^{\circ} \mathrm{C}$ & Nair et al., 2008 \\
\hline From $550 \div 700^{\circ} \mathrm{C}$ and burning time of about 1 hour & $\begin{array}{l}\text { Ganesan et al., 2008; Madandoust et } \\
\text { al., 2011 }\end{array}$ \\
\hline About $650^{\circ} \mathrm{C}$ and burning time of about 1 hour hours & Madandoust et al., 2011 \\
\hline From $600 \div 800^{\circ} \mathrm{C}$ and burning time of 2 hours & Kannan and Ganesan, 2014 \\
\hline About $5500^{\circ} \mathrm{C}$ and burning in 2 hours & Khassaf et al., 2014 \\
\hline From $650 \div 800^{\circ} \mathrm{C}$ and burning time of about 4 hours & Behak, 2017 \\
\hline
\end{tabular}

\subsection{Physical properties of RHA}

Rice husk ash is a porous material with a high amount of honeycomb voids (Adajar et al., 2019; Liu et al., 2019b). In addition, an extra layer with small intragranular voids existed within the RHA structure (Adajar et al., 2019). RHA is also a nonplastic material (Yadav et al., 2017). These properties of RHA will result in the high capacity of water absorption of RHA and can affect the water content, plasticity index of the soil-RHA mixture. Some other physical properties of RHA can affect the effectiveness of RHA in soil improvements such as specific density, particle size, and Blaine fineness. Previous investigations (e.g., Rahman, 1987; Ali, 1992; Ali et al., 1992a, b; Basha, 2005; Choobbasti et al., 2010; Anwar Hossain, 2011; Rao et al., 2012; Fattah et al., 2013; Singhai and Singh, 2014; Yoobanpot and Jamsawang, 2014; Rahman et al., 2014; Akinyele et al., 2015; Yadav et al., 2017) showed that the specific density of RHA varied from 1.89 to 2.37 $\mathrm{g} / \mathrm{cm}^{3}$, which was significantly lower than the specific density of soil, cement, and lime. The specific density of soil mostly ranges from 2.60 to $3.00 \mathrm{~g} / \mathrm{cm}^{3}$ (ASTM D 854-92-Section IV); that of ordinary Portland cement is about $3.15 \mathrm{~g} / \mathrm{cm}^{3}$ (ASTM C110-15); and that of lime (CaO) varies from 3.20 to $3.40 \mathrm{~g} / \mathrm{cm}^{3}$ (National Lime Association, USA). This means that the soil treated with RHA will have a lower density than the untreated soil. The low specific density of RHA also affects the compaction characteristics, such as maximum dry density (MDD) of soil-RHA mixture.

Regarding the particle size of RHA, the amorphous silica in RHA is very reactive, especially when it has a fine grain size (Jongpradist et al., 2018). As reported by Nguyen et al. (2011), the pozzolanic activities decreased as the particle size of RHA increased. Thus, the RHA had to be ground into very fine particles to increase the effectiveness of RHA as a pozzolanic material (Ganesan et al., 2008; Givi et al., 2010). The highest pozzolanic reaction occurred when the amorphous silica in RHA was ground to be about $7000 \mathrm{~cm}^{2} / \mathrm{g}$ (Antiohos et al., 2014). In the literature of using RHA for soil improvement, previous studies showed that the size particles of RHA used was often less than $425 \mu \mathrm{m}$ (e.g., Subrahmanyam et al., 1981; Rahman, 1987; Alhassan and Mustapha, 2007; Sharma, 2008; Brooks, 2009; Roy, 2014; Aziz et al., 2015). The fineness of RHA particles varied from about 3000 $\mathrm{cm}^{2} / \mathrm{g}$ (Ashango and Patra, 2016) up to $130 \times 10^{4}$ $\mathrm{cm}^{2} / \mathrm{g}$ (Choobbasti et al., 2010).

\section{Chemical compositions of RHA}

The chemical compositions of RHA include $\mathrm{SiO}_{2}, \mathrm{Al}_{2} \mathrm{O}_{3}, \mathrm{Fe}_{2} \mathrm{O}_{3}, \mathrm{CaO}, \mathrm{MgO}, \mathrm{Na}_{2} \mathrm{O}$, and $\mathrm{K}_{2} \mathrm{O}$. In which, the silica content is the highest one with more than 70\% (Fapohunda et al., 2017). In general, the silica content in RHA obtained from no-controlled burning rice rusk (open heap 
burning, bio-mass power plants) is often lower than that from controlled burning (Nguyen et al., 2011; Karatai et al., 2016; Liu et al., 2019). The content of silica will reflect the reactivity of RHA since silica was found to be responsible for the pozzolanic reaction. If the sum of $\mathrm{SiO}_{2}+\mathrm{Al}_{2} \mathrm{O}_{3}+$ $\mathrm{Fe}_{2} \mathrm{O}_{3}$ in RHA exceeds 70\%, RHA is classified as Class $\mathrm{F}$ fly ash with high pozzolanic characteristics (ASTM, C618, 2008). In their own study, Fapohunda et al. (2017) reported that the silica content in RHA in various countries was very high and slightly varied from 85 to $95 \%$. For other constituents of RHA, except for $\mathrm{MgO}$ and $\mathrm{K}_{2} \mathrm{O}$, the content was small and less than $1 \%$. Additionally, the loss of ignition (LOI) in all RHA was less than $8 \%$, except for RHA in Nigeria. This indicated that the RHA in those countries were in the same category with Class F fly ash.

\section{Utilization of RHA in soil improvement}

\subsection{The role of RHA in soil improvement}

In general, soil improvement includes two forms: modification and stabilization. Soil modification often creates new materials used for building dam or base, sub-base layers in the road, pavement applications. For soil modification, the physical properties of soil, such as plasticity indices, volumetric stability, expansive potential, hydraulic conductivity, and workability, are immediately improved. For soil stabilization, a significant increase in long-term strength and durability are obtained (Behak, 2017).

Soil stabilization using RHA in terms of strength can be explained based on the pozzolanic reactions. The pozzolanic reactions are formed between silicate oxide $\left(\mathrm{SiO}_{2}\right)$ in RHA and calcium hydroxide $\left(\mathrm{Ca}(\mathrm{OH})_{2}\right)$ in soil mixtures. Thus, chemical binders, such as lime and cement, which can react with water in the soil to form $\mathrm{Ca}(\mathrm{OH})_{2}$ should be used together with RHA to increase the efficiency of RHA in soil improvement. For the mixture of RHA and lime, in the presence of water, the dissolve of $\mathrm{CaO}$ will occur and releases calcium ions $\left(\mathrm{Ca}^{2+}\right)$. The amorphous silica in RHA reacts with cations $\mathrm{Ca}^{2+}$ to form the cementitious product of calcium silicate hydrate (CSH). In the case of a mixture of ordinary Portland cement (OPC) and RHA, the amorphous silica in RHA reacts with the extra lime in the cement, which can be as high as $60 \%$. The pozzolanic reaction to form $\mathrm{CSH}$ gel can be illustrated as follows (Boateng and Skeete, 1990):

$$
\begin{gathered}
\mathrm{Ca}(\mathrm{OH})_{2}+\mathrm{SiO}_{2}=\mathrm{CSH}_{\mathrm{I}}+\mathrm{CSH}_{I I} \\
\text { where: } \\
\mathrm{CSH}_{\mathrm{I}}=\mathrm{CaO}_{0.8-1.5} \mathrm{SiO}_{2 \cdot}\left(\mathrm{H}_{2} \mathrm{O}\right)_{1.0-2.5} \\
\mathrm{CSH}_{\mathrm{II}}=\mathrm{CaO}_{1.5-2.0} \mathrm{SiO}_{2 .} 2\left(\mathrm{H}_{2} \mathrm{O}\right)
\end{gathered}
$$

These products from the pozzolanic reactions in the form of gel will cover and bond the soil particles, which lead to an increase in the strength and durability of soil mixtures. The gels slowly crystallize, which also results in further enhancement in soil strength. The formation of $\mathrm{CSH}$ gel from the pozzolanic reaction was confirmed by the SEM (Scanning Electron Microscope) images, which were reported by Yoobanpot and Jamsawang (2014). In additional to increasing the strength and durability, the CSH gel can also decrease the swelling potential of expansive soil and the permeability. The pozzolanic reaction will occur quickly in a few hours after the addition of water to the mixture and can continue for a long time as long as having enough lime, silica, water, and a high pH (Little, 1999).

The soil modification in terms of physical properties such as water content, plasticity index can be explained based on the structure and nonplastic characteristics of RHA. The honeycomb voids and extra layers in the RHA structure will result in the high capability of water absorption of RHA (Adajar et al., 2019). This capability will decrease the water content of stabilized soil when RHA is mixed with soil. Besides, the hydration process may cause a decrease in water content (Yoobanpot and Jamsawang, 2014). The nonplastic property and water absorption of RHA can lead to a decrease in the plasticity index of the soil mixtures.

Regarding the compaction characteristics, the high water absorption capability of RHA will lead to an increase in the optimum moisture content (OMC) of the soil mixtures. By contrast, the maximum dry density (MDD) of the stabilized soil will be decreased as the RHA content increases due to the lightweight of RHA compared to soil, lime, and cement.

In general, the increase of RHA content will improve the geotechnical properties of improved soil. However, there was a threshold of RHA 
content where the geotechnical properties, especially the strength parameters (e.g., UCS, CBR, and shear strength), were optimized. It means that the strength parameters decrease as the RHA content exceeds the threshold value. Since the RHA is a non-plastic material, the further increase of RHA can reducethe cohesion among particles. Besides, when the RHA is higher than the threshold value, there is not enough water for the pozzolanic reaction. This behavior is similar to the one of adding granulated blast furnace slag (GBFS) and ground granulated blast furnace slag (GGBFS) to the soil mixture (Sekhar et al., 2017; Sharma and Sivapullaiah, 2016).

\subsection{Using RHA without chemical binders}

Although RHA has a little cementitious property, it can be used for soil modification. Alhassan (2008a) used RHA to stabilize the lateritic soil (A-7-6). The research reported that RHA mixing with lateritic soil (A-7-6) could lead to a reduction in the MDD, an increase in the OMC, and a slight rise in unconfined compressive strength (UCS) and California Bearing Ratio (CBR) with increasing RHA content. The optimum RHA content is varied from 6 to $8 \%$. However, the research also indicated that using $6 \div 8 \%$ of RHA has a little potential for strength improvement of A-7-6 lateritic soil. Based on the mixture of RHA and lateritic soil (A-7-6), Alhassan (2008b) also showed that the permeability of the mixture decreased as the increase of RHA content up to $6 \%$ and beyond this point, the permeability slightly rose. For the sub-grade layer, Okafor and Okonkwo (2009) used RHA to stabilize lateritic soil (A-2-6). The research results showed that the increase in RHA content increased the OMC but decreased the MDD. In addition, the increase in RHA content led to decrease plasticity index, increase volume stability, and strength property (CBR). The optimum content of RHA was found to be $10 \%$ for lateritic soil A-2-6. For lateritic soil A7-6 in Bangladesh, Sarkar et al. (2012) showed that the increase of RHA content decreased the plasticity index, swelling index, MDD, compression index (Cc), and increased shear strength (especially frictional angle) and UCS. The study also found that $10 \%$ RHA was the optimum content for the increase of UCS and shear strength of lateritic soil A-7-6. For lateritic clay in Nigeria,
Akinyele et al. (2015) confirmed that RHA can be used as a good stabilizing agent for subgrade in road construction, for backfill in retaining wall. However, the RHA content used should not be higher than $10 \%$.

Besides lateritic soil, RHA was also used to stabilize residual soil (silty sand). The research results of Fattah et al. (2013) showed that the plasticity index of residual soil decreased up to $80 \%$ with the addition of 9\% RHA, the MDD decreased with RHA content up to $9 \%$. There was a significant increase in the UCS of residual soil with increasing RHA content to $6 \div 8 \%$. For residual soil (weathering from granitic rock) in Malaysia, the addition of RHA from 0 to $20 \%$ also decreased the plasticity index, the MDD value, permeability, and increased shear strength parameters (Rahman et al., 2014).

The RHA was also found to be effective for the improvement of expansive clay. Aziz et al. (2015) used the RHA content from $0 \div 20$ to improve expansive clay in Pakistan. The research results showed a significant reduction in the swell potential of soil with the addition of RHA. This is beneficial for problems related to pavements and the foundation on such soils. Furthermore, there was a notable increase in friction angle from the direct shear test with increasing RHA up to $16 \%$. Recently, Adajar et al. (2019) showed that the mixtures of expansive soil and $20 \div 25 \%$ RHA were considered non-expansive soil. The research also presented that the plasticity index of expansive soil decreased as the increase of RHA content. However, a decrease was found in the compaction characteristic and the UCS with increasing RHA. This can be attributed to the presence of RHA which restricts the strength development. In addition, the pozzolanic property of RHA may not enough to produce the cementitious compounds which bind the soil grains. The research result of Ayite et al. (2020) showed that the RHA added to the Togo clay significantly reduced the plasticity index, swelling potential, and increased the soil CBR index. The research also suggested that the mixture of soil with $15 \%$ of RHA can be used as a sub-base course. In general, the RHA without chemical binders was often used to improve lateritic soil, residual soil for the base and subgrade layers, pavement, and backfill in retaining wall. 
The main purposes of this usage are to reduce the plasticity index, and swelling potential of expansive clay. The RHA only has a little potential for the enhancement of the soil strength or even reduces the soil strength.

\subsection{Using RHA with chemical binders}

As mentioned above, the RHA has little potential for increasing the soil strength. Since it has a low cementitious property, it is often used together with chemical binders such as lime and/or cement to improve soil, especially in the view of soil strength. Previous studies showed that the addition of RHA, lime, and/or cement to the soil can decrease plasticity index, MDD, permeability, and increase OMC, UCS, CBR, and shear strength of the soil mixture. Figures 1,2

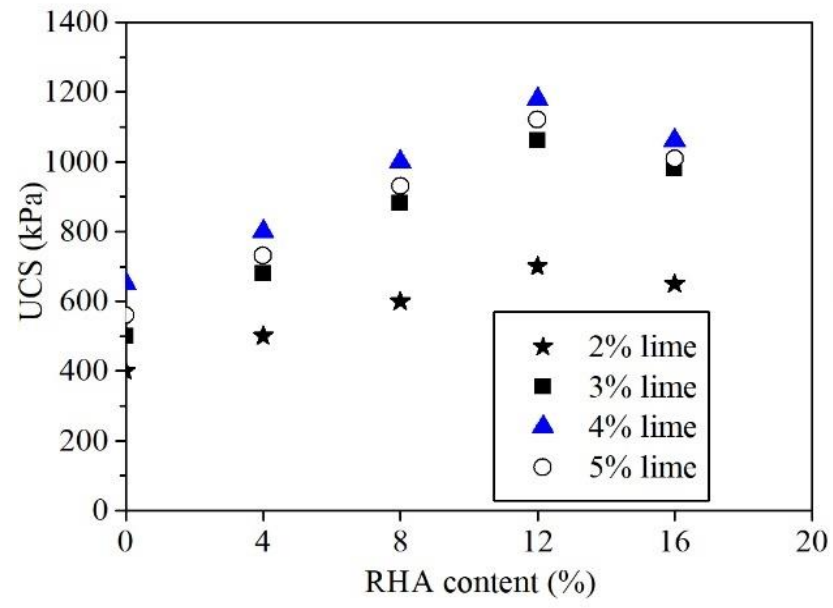

show the increase of some strength parameters with the addition or the replacement of cement by RHA (Sharma et al., 2008; Yoobanpot and Jamsawang, 2014). The strength parameters (UCS, CBR, and shear strength) also increased as the curing time increased. However, there was a threshold content of RHA to optimize the geotechnical properties of improved soil.

Table 2 shows the optimum content of RHA was often used in combination with lime or cement in soil stabilization which was collected from previous studies. It can be seen that the RHAlime and RHA-cement mixtures have been widely used to improve different types of soil. Particularly, the mixture of RHA-lime showed a great potential for the stabilization of expansive soil. In some cases, the RHA can be used together

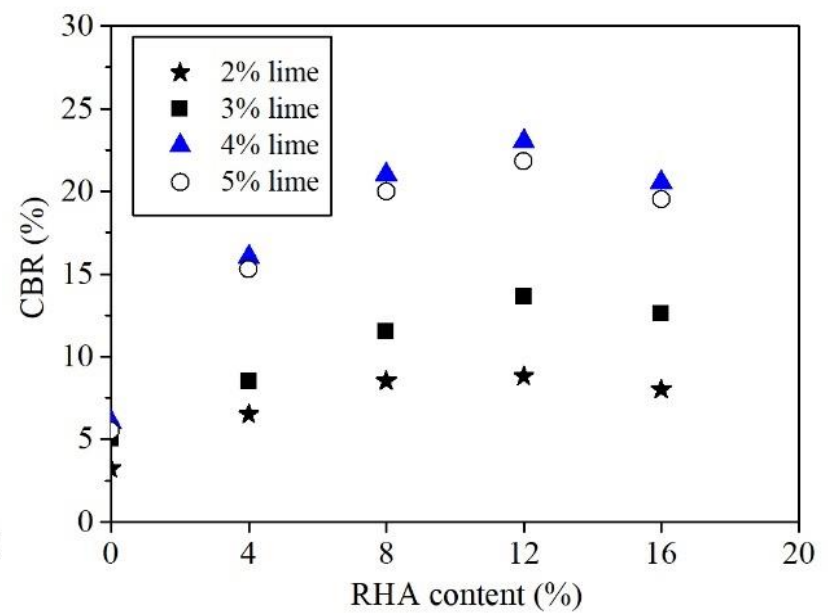

Figure 1. Effect of RHA in combination with lime on UCS and CBR (after Sharma et al., 2008)
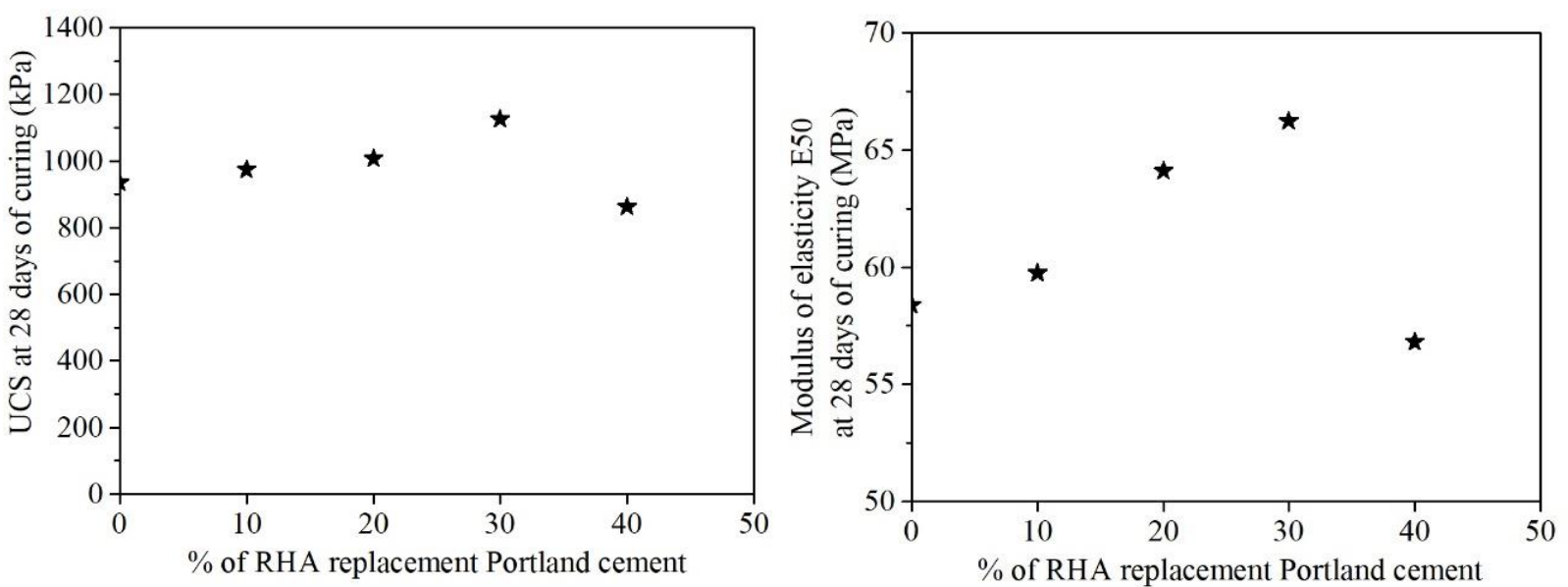

Figure 2. Effect of RHA replacement Portland cement on UCS and E50 of soil-cement admixture (after Yoobanpot and Jamsawang, 2014) 
Table 2. The optimum content of RHA used in combination with lime, cement for soil stabilization in term of soil strength

\begin{tabular}{|c|c|c|c|c|}
\hline Types of soil & RHA (\%) & Lime (\%) & Cement (\%) & Reference \\
\hline $\mathrm{CH}$ soil & 5 & 5 & - & Subrahmanyam et al., 1981 \\
\hline Lateritic soil & 12 & - & 9 & Rahman, 1987 \\
\hline \multirow{2}{*}{ Residual soil } & 6 & - & 9 & \multirow{2}{*}{ Ali et al., 1992a } \\
\hline & 6 & 9 & - & \\
\hline Residual soil & $15 \div 20$ & - & $6 \div 8$ & Basha et al., 2005 \\
\hline Lateritic soil & 4 & - & $2 \div 8$ & Alhassan, 2007 \\
\hline Expansive soil & 16 & $2 \div 5$ & - & Sharma, 2008 \\
\hline Expansive soil & 16 & - & - & Brooks, 2009 \\
\hline Silty clay & 5 & 4 & - & Choobbasti et al., 2010 \\
\hline Clayey soil & 15 & - & $5^{*}$ & Anwar Hossain, 2011 \\
\hline Expansive soil & 20 & 5 & - & Rao et al., 2012 \\
\hline Silty sand & 3.125 & 6.25 & 3.125 & Bagheri et al., 2014 \\
\hline CH soil & 10 & - & 6 & Roy, 2014 \\
\hline $\begin{array}{l}\text { High plasticity clay } \\
\text { (deep mixing method) }\end{array}$ & $30 \%$ cement & - & $200 \mathrm{~kg} / \mathrm{m}^{3}$ & Yoobanpot and Jamsawang, 2014 \\
\hline Residual soil & 8 & - & $10 \div 15$ & Khan et al., 2016 \\
\hline $\begin{array}{l}\mathrm{CH} \text { clay (deep mixing } \\
\text { method) }\end{array}$ & Up to $35 \%$ & - & $10 \div 55$ & Jonpradist et al., 2018 \\
\hline Expansive soil & 12 & 3 & - & Liu et al., $2019 \mathrm{~b}$ \\
\hline Bangkok clay & 10 & $4 \div 12$ & - & Thai and Eisazadeh, 2019 \\
\hline \multicolumn{5}{|c|}{ Note: * Cement Kiln Dust (CKD) } \\
\hline
\end{tabular}

with both cement and lime to enhance the strength of soil (Bagheri et al., 2014). The optimum content of RHA used for soil improvement depends on the types of soil, since RHA reacts differently with different soil types because of their variations in chemical compositions. From the view of engineering purposes, the optimum RHA content often varies from about 3 to $20 \%$ with lime content of 2 to $9 \%$, cement content of 2 to $15 \%$ by dry weight of soil (Table 2). Except for the case of cement deep mixing method to create high-strength cementadmixed clay, the RHA and cement contents could be up to $35 \%$ and $55 \%$ respectively (Jongpradist et al., 2018). Regarding the engineering purposes, the utilization of RHA with lime and/or cement were mainly to improve the strength of local soils for building road (base and sub-base materials) and houses in local areas or to reduce the swelling potential of expansive soil. However, the research on the utilization of RHA in ground improvement by deep mixing method using cement for purposes of building foundation and reducing settlement of ground is still limited. It is, therefore, recommended for further research.

\subsection{Using RHA with other materials}

Besides cement and lime, RHA was also used together with other waste materials such as fly ash, pond ash, steel slag, coir fibre, and calcium carbide residue for soil improvement (Brooks, 2009; Singhai and Singh, 2014; Seco et al., 2011; Ashango and Patra, 2016; Gupta and Kumar, 2017; Abarajithan et al., 2017; Yadav et al., 2017; Liu et al., 2019a). As shown by Brooks (2009), the use of a mixture of RHA and fly ash was good for the preparation of the sub-base material for highway projects. Based on the research results, the RHA of $12 \%$ and fly ash of $25 \%$ were suggested to improve expansive subgrade soil.

The combination of $20 \%$ RHA and $15 \div 20 \%$ fly ash could significantly improve some geotechnical properties of soil, such as plasticity index, swell potential, specific gravity (Singhai and Singh, 2014). Recently, Liu et al. (2019a) 
used the combination of RHA and calcium carbide residue (CCR) to improve the expansive soil. With the addition of RHA and CCR, the swelling potential, swelling pressure, crack quantity, and fineness of expansive soil significantly decreased, whereas, the UCS and shear strength remarkably improved. In general, the combination of RHA with these waste materials can also improve the geotechnical properties of soil, especially the combination of RHA with fly ash and pond ash. However, these combinations are less popular than the combination of RHA with lime and cement for soil improvement.

\section{Conclusions}

From the literature review, there are some man conclusions as follows:

The amorphous silica in RHA depended on both burning temperature and burning duration. The optimum conditions for the production of RHA are burning rice husk in incinerator under a controlled temperature of about $500^{\circ} \mathrm{C}-800^{\circ} \mathrm{C}$ and burning time of about $1 \div 4$ hours.

The utilization of RHA is available to reduce the negative impacts on the environment and the construction cost as well, especially in rural areas. For soil improvement, RHA can be considered as a good stabilizing agent to improve the geotechnical properties of soil such as plasticity index, permeability, swelling pressure, swelling potential, and strength parameters (UCS, CBR, tensile strength, compression, and shear strength). To increase the effectiveness of RHA in soil improvement, RHA was often combined with chemical binders such as lime and cement. Besides, RHA was also used together with other waste materials such as fly ash, steel slag, sugarcane ash, and calcium carbide residue, etc. for soil improvement.

The combination of RHA, lime and cement has been widely investigated to improve different types of soil. From the view of engineering purposes, the RHA from about 3 to $20 \%$ was often suggested in combination with lime of 2 to $9 \%$ and/or cement of $2 \div 15 \%$ to stabilize soil for the base and sub-base layers in roads, pavement applications, and building houses in rural areas.

There are some recommendations for further research:

The utilization of RHA as an additive or as cement replacement in soft ground improvement using deep mixing methodhas great potential and it needs to be further investigated.

The use of RHA in engineering practice is still limited. Moreover, most of the research on the utilization of RHA was carried out in the laboratory. Therefore, the experimental field study regarding the utilization of RHA for soil improvement needs to be conducted.

\section{Acknowledgments}

This research was supported by Hanoi University of Mining and Geology (HUMG) under the project T19-35. I would like to thank my colleagues at the Department of Engineering Geology, HUMG for their suggestions in the implementation of the project.

\section{References}

Abarajithan, G., Rishab Kumar, P., Srikanth, R. (2017). Feasibility of soil stabilization using rice husk ash and coir fibre. Int. J. of Eng. Research \& Technology 6(4). 552-556.

Adajar, M. N. Q., Aquino, C. J. P., Dela Cruz II, J. D., Martin, C. P. H. and Urieta, D. K. G. (2019). Investigating the effectiveness of rice husk ash as stabilizing agent of expansive soil. International Journal of GEOMATE 16. 33-40.

Akinyele, J.O., Salim, R.W., Oikelome, K.O. and Olateju, O.T. (2015) The use of rice husk ash as a stabilizing agent in lateritic clay soil. Int. J. of Civil, Environmental, Structural, Const. and Architectural Engineering 9. 1373-1377.

Alhassan, M. (2008a). Potentials of rice husk ash for soil stabilization. Assumption University Journal of Technology 11(4). 246-250.

Alhassan, M. (2008b). Permeability of lateritic soil treated with lime and rice husk ash. Assumption University Journal of Technology (AUJ.T) 12(2). 115-120.

Alhassan, M., Mustapha, A.M. (2007). Effect of rice husk ash on cement stabilized laterite. Leonardo Electronic Journal of Practices and Technologies 11.47-58.

Ali, F. H, Adana, A., Choy, C. K. (1992b). Use of rice husk ash to enhance lime treatment of soil. Can. Geotech. J. 29. 843-852 
Ali, F.H. (1992). Stabilization of a residual soil. Soils and Foundations 32. 178-185.

Ali, F.H., Adnan, A., Choy, C.K. (1992a). Geotechnical properties of a chemically stabilized soil from Malaysia with rice husk ash as an additive. Geotechnical \& Geological Engineering 10. 117-134.

Al-Khalaf, M.N., Yousif, H.A. (1984). Use of rice husk ash in concrete. Int. J. Cement Composites and Lightweight Concrete 6.

Antiohos, S.K., Papadakis, V.G., Tsimas, S. (2014). Rice husk ash (RHA) effectiveness in cement and concrete as a function of reactive silica and fineness. Cement and Concrete Research 61. 2027.

Anwar Hossain, K.M. (2011). Stabilized soils incorporating combinations of rice husk ash and cement kiln dust. Journal of Materials in Civil Engineering 23. 1320-1327.

Ashango, A.A., Patra, N.R. (2016). Behavior of expansive soil treated with steel slag, rice husk ash, and lime. Journal of Materials in Civil Engineering 28.

ASTM D 854-92. Section IV - Specific gravity of solids determination.

ASTM, C110-15. Test Methods for Physical Testing of Quicklime, Hydrated Lime, and Limestone.

ASTM, C618, 2008. Standard specification for coal fly ash and raw or calcined natural pozzolan for use in concrete. American Society of Testing and Materials. West Conshohocken Pennsylvania, USA.

Ayite, Y. M. X. D., P'Kla, A., Pachoukova, I. (2020). Improvement of Zogbedji (Togo) clay soil characteristics by adding rice husks ashes (RHA). Journal of Scientific and Engineering Research 7(1). 21-26

Aziz, M., Saleem, M., Irfan, M. (2015). Engineering behavior of expansive soils treated with rice husk ash. Geomechanics and Engineering 8, 173-186.

Bagheri, Y., Ahmad, F., Ismail, M.A.M. (2014). Strength and mechanical behavior of soilcement-lime-rice husk ash (soil-CLR) mixture. Materials and Structures 47.55-66.
Basha, E.A., Hashim, R., Mahmud, H.B., Muntohar, A.S. (2005). Stabilization of residual soil with rice husk ash and cement. Const.n and Build. Materials 19. 448-453.

Behak, L., 2017. Soil Stabilization with Rice Husk Ash. Chapter 3 in Rice-Technology and Production.

Boateng, A.A., Skeete, D.A. (1990). Incineration of rice hull for use as a cementitious material: The Guyana experience. Cement and Concrete Research 20, 795-802.

Brooks, R.M. (2009). Soil stabilization with fly ash and rice husk ash. Int. Journal of Research and Reviews in Applied Sciences 1. 209-217.

Bui, D.D., Hu, J., Stroeven, P. (2005). Particle size effect on the strength of rice husk ash blended gap-graded Portland cement concrete. Cement and Concrete Composites 27.357-366.

Choobbasti, A.J., Ghodrat, H., Vahdatirad, M.J., Firouzian, S., Barari, A., Torabi, M., Bagherian, A. (2010). Influence of using rice husk ash in soil stabilization method with lime. Front. Earth Sci. China 4. 471-480.

Cordeiro, G.C., Toledo Filho, R.D., Fairbairn, E. de M.R. (2009). Use of ultrafine rice husk ash with high-carbon content as pozzolan in high performance concrete. Materials and structures 42. 983-992.

Fapohunda, C., Akinbile, B., Shittu, A. (2017). Structure and properties of mortar and concrete with rice husk ash as partial replacement of ordinary Portland cement-A review. International Journal of Sustainable Built Environment 6. 675-692.

Fattah, M.Y., Rahil, F.H., Al-Soudany, K.Y. (2013). Improvement of clayey soil characteristics using rice husk ash. Journal of Civil Engineering and Urbanism 3. 12-18.

Ganesan, K., Rajagopal, K., Thangavel, K. (2008). Rice husk ash blended cement: assessment of optimal level of replacement for strength and permeability properties of concrete. Const. and Build. Materials 22. 16751683.

Givi, A.N., Rashid, S.A., Aziz, F.N.A., Salleh, M.A.M. (2010). Assessment of the effects of rice husk ash particle size on strength, water 
permeability and workability of binary blended concrete. Construction and Building Materials 24. 2145-2150.

Gupta, D., Kumar, A. (2017). Stabilized soil incorporating combinations of rice husk ash, pond ash and cement. Geomechanics and Engineering 12. 85-109.

Hamad, M.A., Khattab, I.A. (1981). Effect of the combustion process on the structure of rice hull silica. Thermochimica Acta 48. 343-349.

Houston, D. F. (1972). Rice hulls. In: RiceChemistry and Technology. American Association of Cereal Chemists, St. Paul, MN. 301-340.

Jongpradist, P., Homtragoon, W., Sukkarak, R., Kongkitkul, W., Jamsawang, P. (2018). Efficiency of rice husk ash as cementitious material in high-strength cement-admixed clay. Advances in Civil Engineering.

Kannan, V., Ganesan, K. (2014). Chloride and chemical resistance of self-compacting concrete containing rice husk ash and metakaolin. Construction and Building Materials 51. 225-234.

Karatai, T.R., Kaluli, J.W., Kabubo, C., Thiong'o, G. (2016) Soil stabilization using rice husk ash and natural lime as an alternative to cutting and filling in road construction. Journal of Construction Engineering and Management 143.

Khan, M. M. H., Loh, E., Singini, P. T., (2016). Stabilization of tropical residual soil using rice husk ash and cement. International Journal of Applied Environmental Science 11(1). 73-87.

Khassaf, S.I., Jasim, A.T., Mahdi, F.K. (2014). Investigation the properties of concrete containing rice husk ash to reduction the seepage in canals. International Journal of Scientific \& Technology Research 3. 348-354.

Little, D.N. (1999). Evaluation of Structural Properties of Lime Stabilized Soils and Aggregates .Volume 1, 1-77

Liu, Y., Chang, C.-W., Namdar, A., She, Y., Lin, C.-H., Yuan, X., Yang, Q. (2019a). Stabilization of expansive soil using cementing material from rice husk ash and calcium carbide residue. Const. and Build. Materials 221. 1-11.
Liu, Y., Su, Y., Namdar, A., Zhou, G., She, Y., Yang, Q. (2019b). Utilization of cementitious material from residual rice husk ash and lime in stabilization of expansive soil. Advances in Civil Engineering.

Madandoust, R., Ranjbar, M.M., Moghadam, H.A., Mousavi, S.Y. (2011). Mechanical properties and durability assessment of rice husk ash concrete. Biosystems Engineering 110. 144152.

Nair, D.G., Fraaij, A., Klaassen, A.A., Kentgens, A.P. (2008). A structural investigation relating to the pozzolanic activity of rice husk ashes. Cement and Concrete Research 38, 861-869.

National Lime Association, USA. Properties of typical commercial lime products.

Nguyen Thi $\mathrm{Nu}$, Bui Truong Son, (2020). Utilisation of ground granulated blast furnace slag (GGBFS) for soft soil improvement by deep mixing method (Vietnamese). Journal of Mining and Earth Sciences 61 (1). 92-100

Nguyen, V. T., Ye, G., Van Breugel, K., Fraaij, A.L., Dai Bui, D. (2011). The study of using rice husk ash to produce ultra-high performance concrete. Cons. and Build. Materials 25. 20302035.

Okafor, F.O., Okonkwo, U.N. (2009). Effects of rice husk ash on some geotechnical properties of lateritic soil. Nigerian J. of Technology 28, 4652.

Phai, H., Eisazadeh, A. (2019). Compaction properties of rice husk ash-lime-Bangkok clay mixtures. Advanced Materials Research IX-Key Engineering Materials 803. 331-337

Pham, V. P., Tran, V. T. (2020). Rice husk ash burnt in simple conditions for soil stabilization. Lecture Notes in Civil Engineering. 717-722.

Rahman, M.A. (1987). Effects of cement-rice husk ash mixtures on geotechnical properties of lateritic soils. Soils and Foundations 27. 61-65.

Rahman, Z.A., Ashari, H.H., Sahibin, A.R., Tukimat, L., Razi, I.W.M. (2014). Effect of rice husk ash addition on geotechnical characteristics of treated residual soil. American-Eurasian Journal of Agricultural \& Environmental Sciences 14. 1368-1377. 
Rao, D.K., Rao, G., Pranav, P.R.T. (2012). A laboratory study on the effect of rice husk ash \& lime on the properties of marine clay. Int J Eng Innov Technol 2. 345-53.

Roy, A. (2014). Soil stabilization using rice husk ash and cement. Int. J. Civil Engineering Research 5. 49-54.

Sarkar, G., Islam, M.R., Alamgir, M., Rokonuzzaman, M. (2012). Interpretation of rice husk ash on geotechnical properties of cohesive soil. Global J. Research in Engineering 12.

Seco, A., Ramírez, F., Miqueleiz, L., García, B. (2011). Stabilization of expansive soils for use in construction. Applied Clay Science 51(3). 348-352.

Sekhar, D. C., Nayak, S., Preetham, H. K. (2017). Influence of granulated blast furnace slag and cement on the strength properties of lithomargic clay. Indian Geotech. J.

Sharma, A. K., Sivapullaiah. (2016). Ground granulated blast furnace slag amended fly ash as an expansive soil stabilizer. Soils and Foundations 56(2), 205-212.

Sharma, R.S., Phanikumar, B.R., Rao, B.V. (2008). Engineering behavior of a remolded expansive clay blended with lime, calcium chloride, and rice-husk ash. Journal of Materials in Civil Engineering 20. 509-515.
Singhai, A.K., Singh, S.S. (2014). Laboratory study on soil stabilization using fly ash and rice husk ash. Int. J. of Research in Engineering and Technology. 2319-1163.

Subrahmanyam, M.S., Cheran, L.L., Cheran, L.S. (1981). Use of rice husk ash for soil stabilization. Geol. Soc. Malaysia. Bulletin 14. 143-151.

Yadav, A.K., Gaurav, K., Kishor, R., Suman, S.K. (2017). Stabilization of alluvial soil for subgrade using rice husk ash, sugarcane bagasse ash and cow dung ash for rural roads. International Journal of Pavement Research and Technology 10. 254-261.

Yeoh, A.K., Bidin, R., Chong, C.N., Tay, C.Y. (1979). The relationship between temperature and duration of burning of rice-husk in the development of amorphous rice-husk ash silica. In: Proceedings of UNIDO/ESCAP/RCTT.

Yoobanpot, N., Jamsawang, P. (2014). Effect of cement replacement by rice husk ash on soft soil stabilization. Kasetsart Journal-Natural Science 48. 323-332.

Yulianto, F.E., Mochtar, N.E. (2010). Mixing of rice husk ash (RHA) and lime for peat soil stabilization. In: Proceedings of the First Makassar International Conference on Civil Engineering. 